International Journal of Social Sciences and Humanities
Available online at www.sciencescholar.us
Vol. 5 No. 3, December 2021, pages: 184-191
e-ISSN: 2550-7001, p-ISSN: 2550-701X
https://doi.org/10.53730/ijssh.v5n3.1609

\title{
The Influence of Service Quality and Price of New Electricity on the Level of Satisfaction By Household Customers
}

\begin{abstract}
CrossMark
Muhammad Hidayat Isnaini a , Zakaria Wahab b , Muchsin Saggaf Shihab c, Sulastri ${ }^{\mathrm{d}}$

Manuscript submitted: 27 August 2021, Manuscript revised: 18 September 2021, Accepted for publication: 09 October 2021

Corresponding Author a

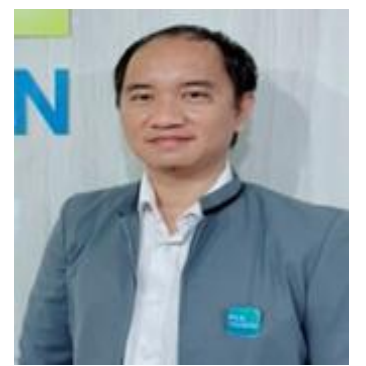

Keywords

Abstract

The new Install process at State Electricity Company (SEC) is the first interaction between prospective customers and SEC. Customers may evaluate and react to the quality of services and the number of new installation costs paid throughout the process. These issues must be addressed very away since they may impact consumer satisfaction with electricity services. This research focuses on customer satisfaction with service quality and pricing perceptions of new pairs at SEC Rivai's Customer Service Unit (CSU). The data utilized is current. Thus it is applicable to present circumstances. However, since the quantity of sample data in this study is still limited, it can only represent customer satisfaction on a single scale, which may be the starting point for future research.
\end{abstract}

customer complaints; customer satisfaction; price perception;

$S E C$;

SERVQUAL;

service quality;

International Journal of Social Sciences and Humanities (C) 2021. This is an open access article under the CC BY-NC-ND license (https://creativecommons.org/licenses/by-nc-nd/4.0/).

\footnotetext{
Contents

Abstract

1 Introduction

2 Materials and Methods

3 Results and Discussions

4 Conclusion Acknowledgments.

${ }^{a}$ Master of Management, Sriwijaya University, Palembang, Indonesia

${ }^{\mathrm{b}}$ Lecturer of Magister Management, Economic Faculty, Sriwijaya University, Palembang, Indonesia

c Lecturer of Bakrie University, Jakarta, Indonesia

${ }^{d}$ Lecturer of Magister Management, Economic Faculty, Sriwijaya University, Palembang, Indonesia
} 185 186 186 


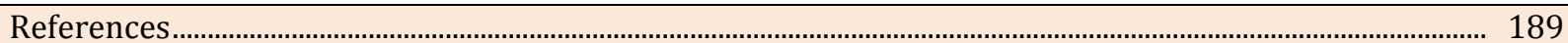

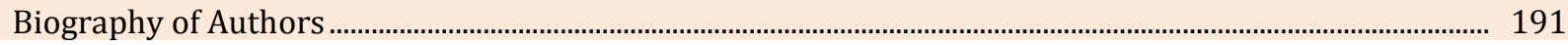

\section{Introduction}

Customer satisfaction is one of SEC's focuses in providing services to customers because over time; several things have changed, customer expectations have also changed following the times and technological advances (Zaini, 2020). Customers can assess and respond to services provided by SEC, and from the results of the assessment results, the level of customer satisfaction can be seen. According to Lovelock \& Wirtz (2011), Satisfaction is an attitude that is decided based on the experience gained. Customer satisfaction is a crucial success factor and long-term competitive advantage for businesses in all industries (Ojo, 2010). Service quality refers to the level of service performance excellence (Zeithaml et al., 1985). There are several services provided by SEC that customers can consider in providing an assessment, such as the quality of electricity reliability, technical complaints, meter reading services, multipurpose services, power changes, and new installation services. Of these services, the new installation service is interesting to study because it is the starting point of SEC's interaction with customers, which can give a good or bad initial impression depending on customer satisfaction. The first law of service quality and productivity is to do it right first (Lovelock \& Wirtz, 2011). Complex experiences reshape customers' thinking about their relationship with the company (Rooney et al., 2021). Consumers' perceived quality affects the willingness of these consumers to buy a product (Dwiarta \& Ardiansyah, 2021). PLN is trying to change from focusing on reliable electricity distribution (supply-driven) to focusing on customer needs (demand-driven) (Shrestha et al., 2020). This is necessary because, as a service provider company, SEC is required to provide the best service for the community in meeting electricity needs and achieving customer satisfaction. According to Kotler \& Armstrong (2008), customer value is the customer's comparison between all the benefits and all the costs that must be incurred to accept the offer given.

According to Kotler (2018), customer satisfaction is a comparison between the impression of the performance (results) of a product with consumers' expectations, which is described by feelings of pleasure or disappointment after using the product. Thus, the Satisfaction of a consumer is highly dependent on the performance of the product (perceived performance) compared to consumer expectations and whether the consumer interprets the existence of deviations or gaps between performance and expectations (Ristanti et al., 2011). New install is a service provided for new prospective customers who want to become customers. The new prospective customer must pay a connection fee (BP) following the provisions stipulated in the Minister of Energy and Mineral Resources No. 27 of 2017 concerning the level of service quality and fees provided by State Electricity (Persero) along with the Minister of Energy and Mineral Resources. No. 18 of 2019 concerning Amendments to the Regulation of the Minister of Energy and Mineral Resources Number 27 of 2017 concerning the Level of Service Quality and Costs Provided by PT SEC (Stevens et al., 2018; Namkung et al., 2011).

Based on the government regulation, the company must ensure that the cost of connecting new pairs must refer to the price that has been set. Transparency and price compatibility are essential in carrying out these government regulations to increase public confidence in conducting transactions. According to McKnight et al. (2002), trust is built between parties who do not know each other either in the interaction or the transaction process. This is because there are still many complaints about the amount of the cost of installing new electricity, which is considered expensive, and there are differences in the costs paid by prospective customers due to the many complaints from prospective SEC customers who feel that the total price paid is more expensive than the regulations set by the government. To respond to this, SEC needs to socialize to the public and prospective customers that the price set by SEC is following government regulations through ministerial regulations. However, because there are still potential customers who choose the practical way and submit the New Install process to others (read: brokers), then the customer's price will be different compared to the prospective customer taking care of the electricity installation process himself (Brady et al., 2002; Brady \& Robertson, 2001).

SEC realizes that customer satisfaction is closely correlated with the company's success in running its business for the long term. The implementation of customer satisfaction surveys can help companies measure

Isnaini, M. H., Wahab, Z., Shihab, M. S., \& Sulastri. (2021). The influence of service quality and price of new electricity on the level of satisfaction by household customers. International Journal of Social Sciences and

Humanities, 5(3), 184-191. https://doi.org/10.53730/ijssh.v5n3.1609 
the level of customer satisfaction with the services that have been provided. Companies that can provide Satisfaction to their customers will form an attachment to each other. The bond between SEC and customers needs to be created to know and understand the wants and needs of customers, whose ultimate goal is to provide excellent service and exemplary service to create customer satisfaction. Service excellence is better service based on service quality. Service excellence has been a long-standing goal for the private sector and is increasing in the government sector for many countries (Gilmore \& D'Souza, 2006). The company will become the customer's leading choice through excellent service because of the quality and service provided to become loyal (Caruana et al., 2000; Babakus \& Boller, 1992).

\section{Materials and Methods}

This study focuses on household tariff customers who apply for new installations at PT SEC (Persero) Rivai Customer Service Unit. The research design used in this study is conclusive causal research. The method of data collection in this study uses the probability sampling method (random sample), which is taking a random sample from the data that has been selected. The questionnaire is a data collection technique done by giving a set of questions or written statements to respondents to answer (Sugiyono, 2010; Lancaster, 2007; Gill \& Johnson, 2002; Irwin, 2013; Mayer, 2015; Walle, 2015). The data analysis that will be carried out in this study consists of research instrument testing, frequency distribution, data normality test, basic assumption test of multiple regression, multiple linear regression test, coefficient of determination test, and hypothesis $\mathrm{F}$ and hypothesis t (Mori \& Ito, 2001; Sihite et al., 2021; Wisudawati, 2019).

\section{Results and Discussions}

Based on testing using SPSS, the Kolmogorov Smirnov test results, multiple linear regression test, regression coefficient test and coefficient of determination, t-test and $\mathrm{f}$ test of each variable used in this study are as follows:

Table 1

SPSS test results

\begin{tabular}{|c|c|c|c|c|c|c|c|c|}
\hline \multicolumn{9}{|c|}{ SPSS Test Results } \\
\hline \multirow{2}{*}{ K-S TEST } & \multicolumn{3}{|c|}{ Multiple Linear Regression } & \multirow{2}{*}{$\mathrm{R}$} & \multirow{2}{*}{ R Square } & \multicolumn{2}{|c|}{ t-test } & \multirow{2}{*}{ f. test } \\
\hline & $\alpha$ & $\mathrm{X} 1$ & $\mathrm{X} 2$ & & & $\mathrm{X} 1$ & $\mathrm{X} 2$ & \\
\hline 0,00 & 0,205 & 0,105 & 0,114 & 0,764 & 0,583 & 3,356 & 1,903 & 67,926 \\
\hline
\end{tabular}

Based on table 1, it can be seen that the data distribution pattern is close to normal. This is shown through the Kolmogorov-Smirnov test, which shows results with a significance level of 0.000 which is below the normal distribution of 0.05 . From table 1 . Above, the results of multiple linear regression analysis can be expressed by the following equation:

$$
Y=0.205+0.105 X_{1}+0.114 X_{2}+e
$$

The linear regression equation above can be translated as follows:

1) The constant value $(\alpha)$ shows a positive value with a value of 0.205 ; without the influence of service quality and price perception, the value of customer satisfaction is 0.205 .

2) The regression coefficient value of the service quality variable is 0.105 with a count of 3.356 , which states that service quality positively affects customer satisfaction. This shows that the higher the level of service quality, the higher it will affect the value of customer satisfaction. 
3) The regression coefficient value of the price perception variable is 0.114 with a count value of 1.903 which states that the price perspective positively affects customer satisfaction. This shows that the better the price perspective obtained by customers in making new pairs, the higher the impact on the value of customer satisfaction.

\section{Correlation coefficient test results ( $r$ ) and coefficient of determination $\left(R^{2}\right)$}

Based on the output model summary in table 1, the results of the correlation coefficient test ( $\mathrm{r}$ ) show that the magnitude of the influence of the service quality variable and the price perspective on customer satisfaction is 0.764 or $76.4 \%$. The number of $R$ square $\left(\mathrm{R}^{2}\right)$ is 0.583 or $58.3 \%$. These figures show how the quality of service and the price perspective affect the Satisfaction of new customers at PT SEC ULP Rivai. This figure explains that how the variables of service quality and price perspective in showing what factors can affect customer satisfaction for new pairs at PT SEC ULP Rivai together is $58.3 \%$, and the remaining $41.7 \%$ is influenced by other factors such as corporate image, the level of customer confidence in the company and other factors (Lii \& Sy, 2009; Price et al., 2007).

\section{Individual parameter significance test results (t-Test)}

Based on table 1 the value of degree of freedom (df) $=100-3=97$ and 0.05 and the formula to find $t$ table: $t$ table $=\mathrm{t}(\mathrm{a} / 2 ; \mathrm{nk}-1)=\mathrm{t}(0.025 ; 97)$ then the value of the table for this research data is 1.984 . The results of the analysis are explained as follows:

1) The count value of the service quality variable (X1) is 3.356 , and the significance value is 0.001 , then the count $>$ table is $(3.356>1.984)$, or the significance value is $0.001<0.05$. This means that service quality has a significant effect on customer satisfaction of SEC ULP Rivai in the process of installing new electricity. This proves that the first hypothesis on the service quality variable has a positive and significant effect and can be accepted.

2) The count value of the price perception variable (X2) is 1.903 , and the significance value is 0.06 , so the count $<$ table is $(1.903<1.984)$, or the significance value is $0.06<0.05$. There is no significant effect of the price perception variable on customer satisfaction of SEC ULP Rivai in the process of installing new electricity. This proves that the second hypothesis on the price perception variable has no positive effect.

\section{Results of testing hypothesis F (Anova)}

Based on the test results as shown in Table 1. The F-count value is 67.926 with a significance level (Sig F) of 0.000. Meanwhile, to determine the F-table, with a significant level of $(\alpha)=5 \%(0.05)$, with $\mathrm{df}=(\mathrm{n}-\mathrm{k}-1)=$ $(100-2-1)=97$ and $\mathrm{k}=2$, so the value The F-table $(5 \% ; 97 ; 5)$ is 2.365 . While the criteria in the decision to test the $\mathrm{F}$ hypothesis are as follows:

1) If the F-count > F-table, then reject Ho and accept Ha, it means that there is a significant effect of service quality and price perception together on customer satisfaction in the new installation process at PT. SEC ULP Rivai.

2) If the value of F-count < F-table, then accepting Ho and rejecting. Ha, it means that there is no significant effect of service quality and price perception on customer satisfaction in the new installation process at PT. SEC ULP Rivai.

F-count value $(67.926)>$ F-table $(2.365)$ or Sig F $(0.000)<\alpha(0.05)$, then $\mathrm{H}_{0}$ is rejected, and $\mathrm{Ha}$ is accepted, meaning that there is a significant effect on service quality and price perception together on customer satisfaction in the new installation process at PT. SEC ULP Rivai. Based on the results of data analysis, the results of the coefficient of determination test are 0.583 (58.3\%), it explains that the effect of service quality and price perception together is $0.417(41.7 \%)$ so that if service quality and price perception are installed New at PT SEC ULP Rivai has increased by $100 \%$, it will be able to increase customer satisfaction at PT SEC

Isnaini, M. H., Wahab, Z., Shihab, M. S., \& Sulastri. (2021). The influence of service quality and price of new electricity on the level of satisfaction by household customers. International Journal of Social Sciences and 
ULP Rivai by $58.3 \%$, on the contrary, if the quality of service and perception of prices at PT SEC ULP Rivai has decreased by $100 \%$, it will be able to reduce customer satisfaction at PT SEC ULP Rivai is 58.3\%. Furthermore, based on the model test results, it was found that there was a significant effect of service quality and price perception on customer satisfaction at PT SEC ULP Rivai. The results of this study explain that the independent variables used in this study can increase customer satisfaction at PT SEC ULP Rivai. The results of this study are in line with research conducted by Juanda (2020); Maulana (2016); Marpaung (2021); Markoni (2015), who get the results that service quality variables (physical evidence, reliability, responsiveness, assurance, and empathy) simultaneously have a significant effect on customer satisfaction and Sintya et al. (2018), who get the results show that the service quality and price variables have a significant effect on customer satisfaction (Gustafsson, 2009; Matzler et al., 2004).

\section{Conclusion}

Based on the results of the discussion in the previous chapter, it can be concluded several things related to service quality and price perception on customer satisfaction as follows:

1) Service quality and price perception have a combined positive effect on customer satisfaction at PT SEC ULP Rivai. This is shown in the results of data analysis that obtained the test results of a coefficient of determination of $0.583(58.3 \%)$; it explains that the effect of service quality and price perception together is 0.417 (41.7\%), so that if service quality and the perception of new tide prices at PT SEC ULP Rivai has increased by $100 \%$, it will be able to increase customer satisfaction at PT SEC ULP Rivai by $58.3 \%$, on the contrary, if service quality and price perceptions at PT SEC ULP Rivai have decreased by $100 \%$, it will be able to reduce customer satisfaction at PT SEC ULP Rivai by $58.3 \%$.

2) Service quality variable affects customer satisfaction by 0.105 (10.5\%) (directly proportional). So, if the quality of new installation services run by PT SEC ULP Rivai has increased by $100 \%$, it will be able to increase customer satisfaction at SEC ULP Rivai by $10.5 \%$, on the contrary, if the quality of new installation services run by PT SEC ULP Rivai has decreased by $100 \%$, it will be able to reduce customer satisfaction at PT SEC ULP Rivai by $10.5 \%$.

3) The price perception variable has a regression coefficient of 0.114 . This means that the price perspective variable affects the Customer Satisfaction variable (Y) by 0.114 (11.4\%) (directly proportional). So if the perspective of the new tide price received by PT SEC ULP Rivai customers has increased by $100 \%$, it will be able to increase customer satisfaction at PT SEC ULP Rivai by $11.4 \%$, on the contrary, if the perspective of the new tide price received by PT SEC ULP customers Rivai has decreased by $100 \%$, it will be able to reduce Customer Satisfaction at PT SEC ULP Rivai by $11.4 \%$.

\section{Acknowledgments}

Authors put higher application for both supports academically and financially given by the university. Without these useful support and feedbacks we will not be able to complete this project. 


\section{References}

Babakus, E., \& Boller, G. W. (1992). An empirical assessment of the SERVQUAL scale. Journal of Business research, 24(3), 253-268. https://doi.org/10.1016/0148-2963(92)90022-4

Brady, M. K., \& Robertson, C. J. (2001). Searching for a consensus on the antecedent role of service quality and satisfaction: an exploratory cross-national study. Journal of Business research,51(1), 53-60. https://doi.org/10.1016/S0148-2963(99)00041-7

Brady, M. K., Cronin Jr, J. J., \& Brand, R. R. (2002). Performance-only measurement of service quality: a replication and extension. Journal of business research, 55(1), 17-31. https://doi.org/10.1016/S01482963(00)00171-5

Caruana, A., Ewing, M. T., \& Ramaseshan, B. (2000). Assessment of the three-column format SERVQUAL: An experimental approach. Journal of business research, 49(1), 57-65. https://doi.org/10.1016/S01482963(98)00119-2

Dwiarta, I. M. B., \& Ardiansyah, R. W. (2021). The Effect Of Price Perception, Quality Perception, And Location On Purchase Decisio. International Journal of Economics, Business and Accounting Research (IJEBAR), 5(2).

Gill, J., \& Johnson, P. (2002). Research methods for managers. Sage.

Gilmore, A., \& D’Souza, C. (2006). Service excellence in e-governance issues: An Indian case study. Joaag, 1(1), $1-14$

Gustafsson, A. (2009). Customer satisfaction with service recovery. Journal of business research, 62(11), 1220 1222. https://doi.org/10.1016/j.jbusres.2008.11.001

Irwin, S. (2013). Qualitative secondary data analysis: Ethics, epistemology and context. Progress in development studies, 13(4), 295-306.

Juanda, S. G. H. (2020). Pengaruh Kualitas Pelayanan Terhadap Kepuasan Pelanggan Dalam Menggunakan Listrik Prabayar Pada PT. PLN (Persero) Rayon Sekayu. Jurnal Manajemen Kompeten, 2(2).

Kotler, P. (2018). Manajemen Pemasaran edisi 13 jilid 1.

Kotler, P., \& Armstrong, G. (2008). Prinsip-prinsip pemasaran (Vol. 12, No. 01). edisi.

Lancaster, G. (2007). Research methods in management. Routledge.

Lii, Y. S., \& Sy, E. (2009). Internet differential pricing: Effects on consumer price perception, emotions, and behavioral responses. Computers in Human Behavior, 25(3), 770-777. https://doi.org/10.1016/j.chb.2009.02.005

Lovelock, C., \& Wirtz, J. (2011). Pemasaran jasa perspektif. Jakarta: Erlangga.

Markoni, M. (2015). Analisis Kepuasan Pelanggan PT PLN (Persero) terhadap Proses Pemasangan Listrik Prabayar (Studi Kasus PT PLN Ws2jb Rayon Sukarami). Jurnal Manajemen dan Bisnis Sriwijaya, 13(4), 487489.

Marpaung, L., (2021). Pengaruh Disiplin Kerja Dan Budaya Organisasi Terhadap Motivasi Kerja Serta Dampaknya Pada Kinerja Pegawai PT. PLN (PERSERO) UP3 Ogan Ilir (PhD Thesis). 021008 Universitas Tridinanti Palembang.

Matzler, K., Bailom, F., Hinterhuber, H. H., Renzl, B., \& Pichler, J. (2004). The asymmetric relationship between attribute-level performance and overall customer satisfaction: a reconsideration of the importanceperformance analysis. Industrial marketing management, 33(4), 271-277. https://doi.org/10.1016/S00198501(03)00055-5

Maulana, A. S. (2016). Pengaruh kualitas pelayanan dan harga terhadap kepuasan pelanggan PT. TOI. Jurnal Ekonomi Universitas Esa Unggul, 7(2), 78663.

Mayer, I. (2015). Qualitative research with a focus on qualitative data analysis. International Journal of Sales, Retailing \& Marketing, 4(9), 53-67.

McKnight, D. H., Choudhury, V., \& Kacmar, C. (2002). The impact of initial consumer trust on intentions to transact with a web site: a trust building model. The journal of strategic information systems, 11(3-4), 297323.

Mori, H., \& Ito, K. (2001). The Sec protein-translocation pathway. Trends in microbiology, 9(10), 494-500. https://doi.org/10.1016/S0966-842X(01)02174-6

Namkung, Y., Jang, S. S., \& Choi, S. K. (2011). Customer complaints in restaurants: Do they differ by service stages and loyalty levels?. International Journal of Hospitality Management, 30(3), 495-502. https://doi.org/10.1016/j.ijhm.2010.07.005

Isnaini, M. H., Wahab, Z., Shihab, M. S., \& Sulastri. (2021). The influence of service quality and price of new electricity on the level of satisfaction by household customers. International Journal of Social Sciences and 
Ojo, O. (2010). The relationship between service quality and customer satisfaction in the telecommunication industry: Evidence from Nigeria. BRAND. Broad Research in Accounting, Negotiation, and Distribution, 1(1), 88-100.

Price, M., Cameron, R., \& Butow, P. (2007). Communicating risk information: the influence of graphical display format on quantitative information perception-accuracy, comprehension and preferences. Patient Education and Counseling, 69(1-3), 121-128. https://doi.org/10.1016/j.pec.2007.08.006

Ristanti, V., Shihab, M. S., \& Rekarti, E. (2011). Pengaruh Dimensi Kualitas Pelayanan dan Kepuasan Terhadap Loyalitas Pelanggan. Jurnal Manajemen dan Bisnis Sriwijaya, 9(17), 1-12.

Rooney, T., Krolikowska, E., \& Bruce, H. L. (2021). Rethinking relationship marketing as consumer led and technology driven: propositions for research and practice. Journal of Relationship Marketing, 20(1), 42-61.

Shrestha, J. I. B. A. N., Subedi, S. U. B. A. S. H., Timsina, K. P., Chaudhary, A., Kandel, M., \& Tripathi, S. (2020). Conservation agriculture as an approach towards sustainable crop production: A review. Farming and Management, 5(1), 7-15.

Sihite, M., Manullang, S. O., \& Nugroho, B. S. (2021). Relevance of mastery of information systems skills and success of business management in the digital age: a systematic review. International Journal of Social Sciences and Humanities, 5(2), 68-78. https://doi.org/10.29332/ijssh.v5n2.1139

Sintya, L. I., Lapian, S. J., \& Karuntu, M. M. (2018). Pengaruh harga dan kualitas layanan terhadap kepuasan pelanggan jasa transportasi Go-jek online pada mahasiswa FEB Unsrat Manado. Jurnal EMBA: Jurnal Riset Ekonomi, Manajemen, Bisnis dan Akuntansi, 6(3).

Stevens, J. L., Spaid, B. I., Breazeale, M., \& Jones, C. L. E. (2018). Timeliness, transparency, and trust: A framework for managing online customer complaints. Business Horizons, 61(3), 375-384. https://doi.org/10.1016/j.bushor.2018.01.007

Sugiyono, S. (2010). Metode penelitian kuantitatif dan kualitatif dan R\&D. Alfabeta Bandung.

Walle, A. H. (2015). Qualitative research in business: A practical overview.

Wisudawati, N. N. S. (2019). Development of vineyard agritourism through educational tour packages to sustain the local potential. International Journal of Social Sciences and Humanities, 3(2), 294-301. https://doi.org/10.29332/ijssh.v3n2.336

Zaini, Z. (2020). Transformasi PLN: Anti Blackout; Mitigasi Agar Padam Massal Tidak Berulang.

Zeithaml, V. A., Parasuraman, A., \& Berry, L. L. (1985). Problems and strategies in services marketing. Journal of marketing, 49(2), 33-46. 


\section{Biography of Authors}

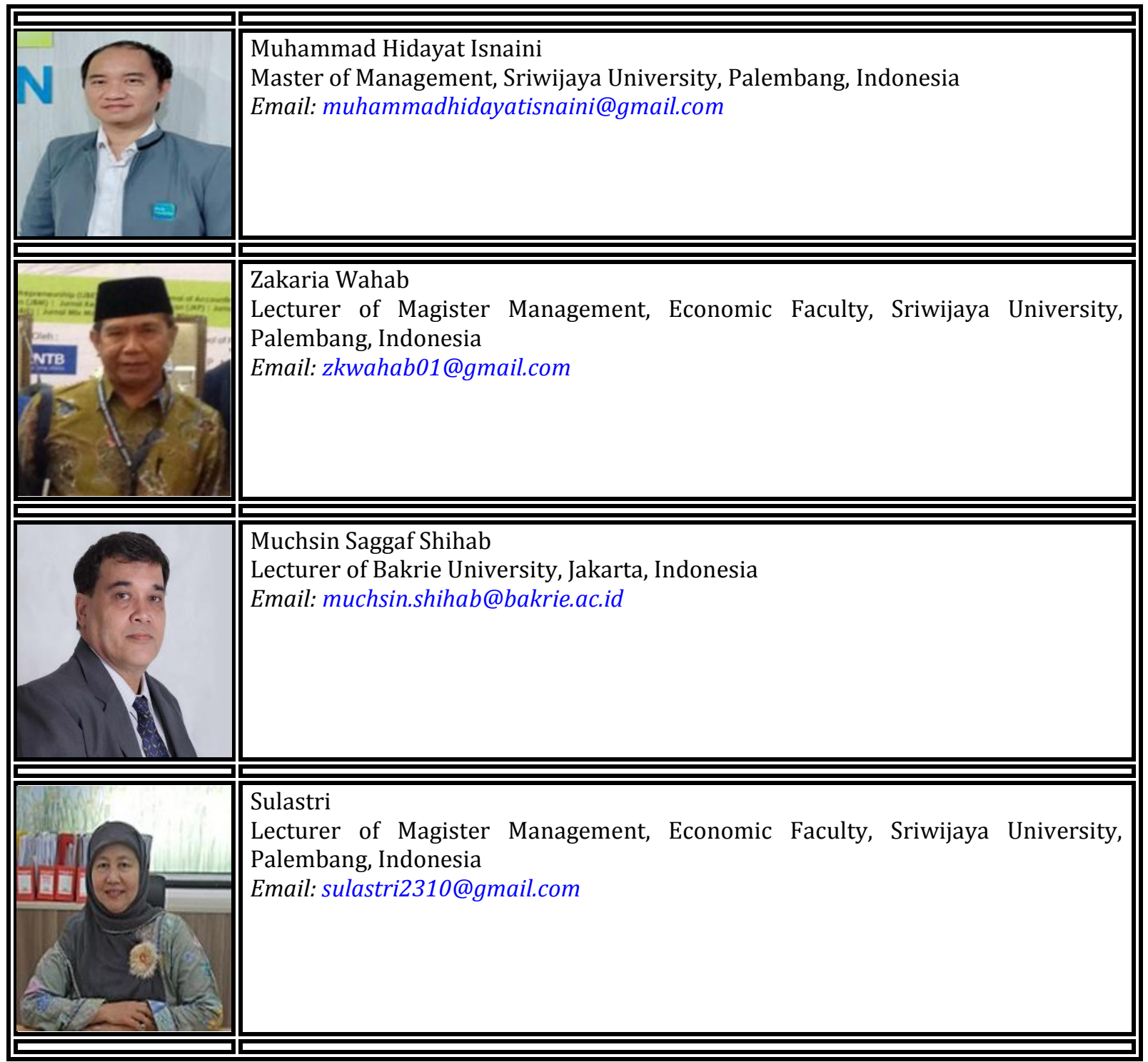

Isnaini, M. H., Wahab, Z., Shihab, M. S., \& Sulastri. (2021). The influence of service quality and price of new electricity on the level of satisfaction by household customers. International Journal of Social Sciences and Humanities, 5(3), 184-191. https://doi.org/10.53730/ijssh.v5n3.1609 